 \\ MASTER
}

Argonne Mational Laboratom

A CALCULATION ON THE EFFECT OF

NONHOMOGENEITY ON THE DETERMINATION OF THE RATE CONSTANT OF A BIMOLECULAR, SECOND-ORDER REACTION

by

Myran C. Saver, Jr. 


\section{DISCLAIMER}

This report was prepared as an account of work sponsored by an agency of the United States Government. Neither the United States Government nor any agency Thereof, nor any of their employees, makes any warranty, express or implied, or assumes any legal liability or responsibility for the accuracy, completeness, or usefulness of any information, apparatus, product, or process disclosed, or represents that its use would not infringe privately owned rights. Reference herein to any specific commercial product, process, or service by trade name, trademark, manufacturer, or otherwise does not necessarily constitute or imply its endorsement, recommendation, or favoring by the United States Government or any agency thereof. The views and opinions of authors expressed herein do not necessarily state or reflect those of the United States Government or any agency thereof. 


\section{DISCLAIMER}

Portions of this document may be illegible in electronic image products. Images are produced from the best available original document. 
The facilities of Argonne National Laboratory are owned by the United States Government. Under the terms of a contract (W-31-109-Eng-38) between the U. S. Atomic Energy Commission, Argonne Universities Association and The University of Chicago, the University employs the staff and operates the Laboratory in accordance with policies and programs formulated, approved and reviewed by the Association.

\section{MEMBERS OF ARGONNE UNIVERSITIES ASSOCIATION}

The University of Arizona Carnegie Institute of Technology

Case Institute of Technology

The University of Chicago

University of Cincinnati

Illinois Institute of Technology

University of Illinois

Indiana University

Iowa State University
The University of Iowa Kansas State University The University of Kansas Loyola University Marquette University Michigan State University The University of Michigan University of Minnesota University of Missouri
Northwestern University University of Notre Dame The Ohio State University Purdue University Saint Louis University Washington University Wayne State University The University of Wisconsin

\section{LEGAL NOTICE}

This report was prepared as an account of Government sponsored work. Neither the United States, nor the Commission, nor any person acting on behalf of the Commission:

A. Makes any warranty or representation, expressed or implied, with respect to the accuracy, completeness, or usefulness of the information contained in this report, or that the use of any information, apparatus, method, or process disclosed in this report may not infringe privately owned rights; or

B. Assumes any liabilities with respect to the use of, or for damages resulting from the use of any information, apparatus, method, or process disclosed in this report.

As used in the above, "person acting on behalf of the Commission" includes any employee or contractor of the Commission, or employee of such contractor, to the extent that such employee or contractor of the Commission, or employee of such contractor prepares, disseminates, or provides access to, any information pursuant to his employment or contract with the Commission, or his employment with such contractor.

Printed in the United States of America

Available from

Clearinghouse for Federal Scientific and Technical Information

National Bureau of Standards, U. S. Department of Commerce

Springfield, Virginia 22151

Price: Printed Copy $\$ 3.00$; Microfiche $\$ 0.65$ 


\section{?}

$-\ldots \ldots \ldots \ldots$

ANL- 7327

Chemistry (TID-4500)

AEC Research and

Development Report

ARGONNE NATIONAL LABORATORY

9700 South Cass Avenue

Argonne, Illinois 60439

\section{CRGS RPICAS}

Ha: $3.00 \cdot 65$

A CALCULATION ON THE EFFECT OF

NONHOMOGENEITY ON THE DETERMINATION

OF THE RATE CONSTANT OF A BIMOLECULAR, SECOND-ORDER REACTION

by

Myran C. Sauer, Jr.

Chemistry Division

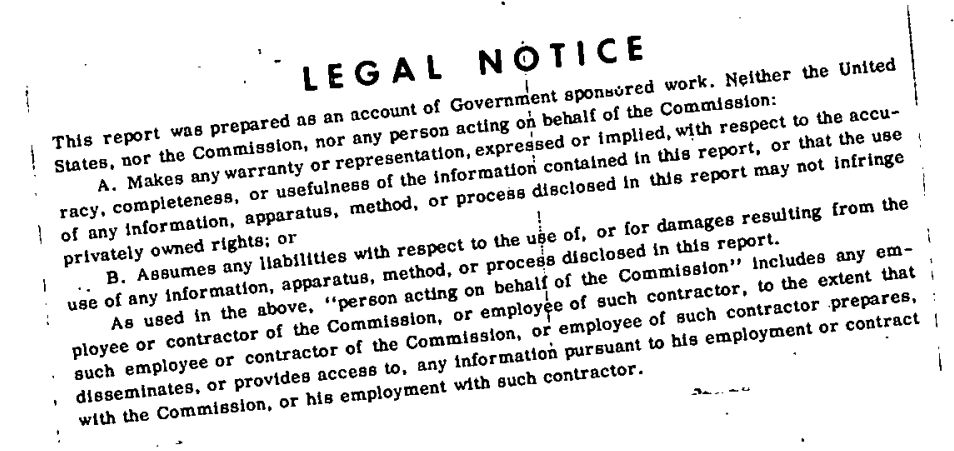

May 1967 


\title{
A CALCULATION ON THE EFFECT OF \\ NONHOMOGENEITY ON THE DETERMINATION \\ OF THE RATE CONSTANT OF A BIMOLECULAR, SECOND-ORDER REACTION
}

by

Myran C. Sauer, Jr.

\begin{abstract}
ABSTRAC'T'
In pulse-radiolysis experiments, where a beam of electrons is absorbed by a sample, thereby producing chemical transients, the concentration of the transients is often not uniform, due to attenuation and scattering of the electron beam as it passes through the sample. This report presents a calculation showing that, for a chemical transient that disappears by a bimolecular, second-order reaction, wide variation in initial concentration throughout the reaction cell has a negligible effect on the slope of a plot of the reciprocal of concentration vs time, which is contrary to intuition.
\end{abstract}

\section{DISCUSSION}

- Although the calculations to be shown are generally applicable, the calculation has been made specifically to analyze the situation in which a cylindrical cell, ${ }^{1} 13 \mathrm{~cm}$ long and about $2 \frac{1}{2} \mathrm{~cm}$ in diameter, is irradiated with a 12 to $15-\mathrm{MeV}$ electron beam, which enters the cell from one end. If the cell is filled with argon at 900 psi, the energy deposited per unit volume in the gas drops by a factor of about 3.5, going from the front to the back of the cell, due mainly to scattering of the electron beam. Hence, the distribution of transient species is quite nonuniform. Calculations have been made for two assumed situations: (A) where the energy deposited decreases linearly along the cell length, and (B) where the decrease is exponential. The average concentration of transient is determined by the absorption of a beam of light passing lengthwise through the cell. ${ }^{1}$

\section{A. Linear Decrease in Energy Deposition}

The initial concentration of transient through the cell is defined by the following equation:

\footnotetext{
${ }^{1}$ M. C. Sauer, Jr. and L. M. Dorfman, J. Am. Chem, Soc. 87, 3801 (1965).
} 


$$
C_{0, x}=C_{0}^{0}\left[1-\left(\frac{1-r}{x_{f}}\right) x\right]
$$

where

and

$$
\begin{aligned}
\mathrm{C}_{0, \mathrm{x}}= & \text { initial concentration of transient at position } \mathrm{x} \text { in cell, } \\
\mathrm{C}_{0}^{0}= & \text { initial concentration of transient at front end of cell } \\
& \text { (where the electron beam enters), } \\
\mathrm{x}= & \text { distance along cell, measured from front end = zero, } \\
\mathbf{x}_{\mathrm{f}}= & \text { length of cell, }
\end{aligned}
$$

$$
\begin{aligned}
& r=\text { ratio of the initial concentration of transient at front end } \\
& \text { to that at back end of cell. }
\end{aligned}
$$

1 If the transient would disappear by a bimolecular, second-order process in the absence of effects due to nonuniformity of concentration, then at any position $\mathrm{x}$ in the cell (neglecting diffusion),

$$
\frac{1}{C_{t, x}}=\frac{1}{C_{0, x}}+a t
$$

where $C_{t, x}$ is the concentration at time $t$ and position $x$, a is the rate constant, and $t$ is the time, measured relative to zero time being the end of the electron pulse.

Equations 1 and 2 can be combined and rearranged to yield

$$
C_{t, x}=\frac{C_{0}^{0}\left[1-\left(\frac{1-r}{x_{f}}\right) x\right]}{1+C_{0}^{0}\left[1-\left(\frac{1-r}{x_{f}}\right) x\right] \text { at }}
$$

The average concentration as a function of time is given by

$$
C_{a v g}=\frac{\int_{x=0}^{x=x_{f}} \cdot C_{t, x} d x}{x_{f}} .
$$

Integration of Eq. 4 yields

$$
C_{\text {avg }}=\frac{C_{0}^{0}}{T}\left[1+\frac{1}{T(1-r)} \log _{e}\left(\frac{1+r T}{1+T}\right)\right],
$$

where $\mathrm{T}=\mathrm{C}_{0}^{0}$ at. 
Using Eq. 5, we can examine the behavior of the average concentration (which is equivalent to what we observe experimentally) as a function of time. Table I gives $C_{0}^{0} / C_{a v g}$ for various values of $T$, as well as the slopes of $\mathrm{C}_{0}^{0} / \mathrm{C}_{\mathrm{avg}}$ between successive points, for several values of $\mathrm{r}$, including the case of uniform concentration, $r=1.0$.

TABLE I. Linear Decrease in Energy Deposition

\begin{tabular}{|c|c|c|c|c|c|c|c|c|c|c|}
\hline \multicolumn{3}{|c|}{$r=0$} & \multicolumn{2}{|c|}{$\mathbf{r}=0.1$} & \multicolumn{2}{|c|}{$r=0.2$} & \multicolumn{2}{|c|}{$r=0.5$} & \multicolumn{2}{|c|}{$r=1.0$} \\
\hline $\mathrm{T}$ & $C_{0}^{0} / C_{a v g}^{(b)}$ & Slope & $\mathrm{C}_{0}^{0} / \mathrm{C}_{\mathrm{avg}}$ & Slope & $\mathrm{C}_{0}^{0} / \mathrm{C}_{\mathrm{avg}}$ & Slope & $\mathrm{C}_{0}^{0} / \mathrm{C}_{\mathrm{avg}}$ & Slope & $\mathrm{C}_{0}^{0} / \mathrm{C}_{\mathrm{avg}}$ & Slope \\
\hline $0(a)$ & 2.00 & & 1.817 & & 1.667 & & 1.333 & & 1.00 & \\
\hline 1 & 3.24 & 1.24 & 2.98 & 1.16 & 2.76 & 1.09 & 2.36 & 1.03 & 2.00 & 1.00 \\
\hline 5 & 7.78 & 1.14 & 7.22 & 1.06 & 6.89 & 1.03 & 6.37 & 1.00 & 6.00 & 1.00 \\
\hline 10 & 13.17 & 1.08 & 12.32 & 1.02 & 11.95 & 1.01 & 11.38 & 1.00 & 11.0 & 1.00 \\
\hline 50 & 54.1 & $\overline{1.02}$ & 52.5 & $\overline{1} . \overline{005}$ & 52.0 & 1.00 & 51.4 & 1.00 & 51.0 & $1 . \overline{00}$ \\
\hline 100 & 104.8 & 1.01 & 102.4 & 1.00 & 102.0 & 1.00 & 101.4 & 1.00 & 101.0 & 1.00 \\
\hline
\end{tabular}

(a) The value of $C_{0}^{0} / C_{a v g}$ for $T=0$ can be shown to be given by $2 /(1+r)$.

(b) The values of $C_{0}^{0} / C_{a v g}$ reflect the value of $C_{a v g}$, since $C_{0}^{0}$ is a constant.

In many experimental situations, the decay of $\mathrm{C}_{\mathrm{avg}}$ cannot be followed over more than three half-lives. Therefore, the values of $\mathrm{C}_{0}^{0} / \mathrm{C}_{\text {avg }}$ for $\mathrm{T}=0$ through 10 are the most significant. In this range of $T, C_{a v g}$ decreases by a factor of $1 / 6.58$ for $r=0$, and $1 / 11$ for $r=1.0$. The value of the slope for $r=1.0$ is, of course, 1.00 ; the deviation from this value for other values of $r$ indicates the error in the determination of the rate constant, a, resulting from the nonhomogeneous concentration. The important fact is that if $r \geq 0.2$, and the experimental results a re analyzed over two or three halflives, an error in the value of a of no more than $5 \%$ will result. Even for smaller values of $r$, the error will not be more than about $10 \%$, under the same conditions of analysis.

\section{B. Exponential Decrease in Energy Deposition}

Using the same symbolism as before, we obtain

$$
C_{0, x}=C_{0}^{0} e^{-b x}
$$

where $b$ is given by

$$
e^{-b x_{f}}-r
$$

These equations take the place of Eq. l, and the same process of determining $\mathrm{C}_{\mathrm{avg}}$ is followed. In this case, the result of the integration is 


$$
C_{\text {avg }}=\frac{C_{0}^{0}}{T}\left\{1-\frac{1}{\log _{e} r}\left[\log _{e}\left(\frac{T+1}{T+1 / r}\right)\right]\right\} .
$$

In this case also, the value of the slope, determined over the first three halflives, is within about $5 \%$ of the correct value (1.00), as can be seen from the results in Table II for $r=0.2$.

TABLE II. Exponential Decrease in Energy Deposition for $r=0.2$

\begin{tabular}{ccc}
\hline$T$ & $\mathrm{C}_{0}^{0} / \mathrm{C}_{\mathrm{avg}}$ & Slope \\
\hline $0(\mathrm{a})$ & 2.02 & 1.13 \\
1 & 3.15 & 1.04 \\
5 & 7.32 & 1.01 \\
10 & 12.38 & $-\frac{1}{1.00}--\frac{1.00}{50}-\frac{52.4}{100}$ \\
\hline
\end{tabular}

(a) The values of $\mathrm{C}_{0}^{0} / \mathrm{C}_{\text {avg }}$ for $\mathrm{T}=0$ can be shown to be given by $(1-r) / \log _{e}(1 / r)$.

The effect of diffusion on the initial distribution of transient has not been considered. However, this would cause the distribution to become more uniform throughout the cell, and would therefore lead to a nearer approximation of the slope to the actual rate constant. 
